the US Atomic Energy Commission and then the Department of Energy. Because departments of government fight for what they have, particle physics has been supported generously, and often in the face of resentment by those who must struggle with the indignities of peer-review. But the downside of that privilege, now apparent, is that there has been no shield between particle physics and the Congress. When notoriously fickle representatives could be counted on to regard particle physics as an element in the struggle with the Soviet Union, that did not matter. Now, for all the extra trouble that would be involved, the National Science Foundation might be a better sponsor for the long run.

\section{Is virtual reality real?}

Virtual reality may be more than an extension of the cinema, but quite what is not yet clear.

WHAT is virtual reality if it is not simply a verbal joke or a pursuit for teenagers in games arcades? Plainly, there is more to be said of it than can be learned from young people wearing strange helmets about the sensory organs carried externally on their heads. Two weeks ago, the US Institution of Electrical and Electronic Engineers (IEEE) held a meeting in New York intended to help endow virtual reality with professional clothes. Separately, it has formed technical and standards committees to give shape to this emerging field, somewhere between psychology and computer science. But just what virtual reality may be is still not crystal clear.

Whatever it is, virtual reality has its roots in the age-old craft of manufacturing illusion, of which it might be held that the classical high-point is the cinema; a person spellbound for an hour and a few minutes by High Noon is indeed immersed in a reality that never was, a railway town in the Western desert of the United States a century ago. It hardly matters that the film is not in colour; indeed, that may help a person to distinguish the real reality from the false. But now, of course, the technical means of representing reality are far superior and are no longer confined to the cinema screen, but may be directly linked to the human brain's own input-output devices, slow (by mechanical standards) though they may be. But that is only a way of going to the cinema by putting a helmet on your head.

True virtual relationists have more powerful ambitions. Beyond immersion in a manufactured reality comes the ability to move about within it (or to change perspective) and, then, to interact with it. Kicha Ganapathy from AT\&T Bell Laboratories said in New York that interaction is essential, realism less so. Although these criteria may be satisfied in playing chess against an opponent no more substantial than a computer program, more than that is intended. The manufactured reality must be a representation of a manufactured world, complexity and all.

Where will all this lead? Arcade games are already on the way. Psychologists will no doubt learn much of people's behaviour in variously manufactured worlds. Teaching people skills, from driving cars and piloting aircraft to speaking foreign languages conversationally, is within the sights of the helmet-builders. But is it possible that the explanation of the interest of the major telecommunications companies in virtual reality has something to do with the prospect that when US Vice President Al Gore has provided the United States with his promised electronic superhighway, the need (and opportunity) will be to find ways of using that vast communications capacity? Arno Penzias, research director at AT\&T, almost admitted as much in New York.

\section{Step back in Ulster}

\section{After another bomb, long-term institution building should} be the goal in Northern Ireland.

Wнат is to be done about Northern Ireland? Since the present wave of troubles began in 1969, that question has provoked nothing but despair from the governments of the United Kingdom and the Irish Republic, not to mention those who live in the province and the many battalions of British troops drafted there in a hopeless attempt to keep the peace. But for the past few weeks, there have been repeated suggestions from official and unofficial sources that constructive talks were under way. What, for Northern Ireland, more natural than that the latest act of violence should have been last Saturday? The explosion of a bomb in a fishmonger's shop in the Protestant district of Belfast killed ten people. Talk of truce, even armistice, has fallen off while Roman Catholics brace themselves for retaliation.

This is not the first time that hopes have been dashed in Northern Ireland. Nor is it likely to be the last; the roots of the conflict are too ancient for that. But the present dynamics are all too clear. The Irish Republican Army (IRA), illegal both in Northern Ireland and in the republic, wants to drive the British Army out of Northern Ireland; its more distant goal of a united Ireland is not, as it would be delivered, likely to be welcome to the government in Dublin. The activities of the IRA provoked the existence of retaliatory (and also illegal) armed bands, now free-standing, which are capable of equally ghastly murders. It is not known to what extent the sustenance of the opposing groups by the communities they claim to represent is voluntary or coercive, but each has some of the attributes of a protection racket.

It is appalling that such circumstances should persist in an otherwise cultivated society. The present British and Irish governments are cooperating fruitfully on immediate and even some distant problems. But in case immediate solutions are beyond reach, they need a recipe for the more distant future. Because community separation is reinforced by sectarian education, should that not be abolished in Northern Ireland - even if that means abolishing sectarian education in the rest of the United Kingdom? And why not build on an imaginative scheme by the University of Ulster to build a new campus in Belfast in part of a no-man's-land separating the two communities by integrating all of Ireland's universities into a single system? Then at least there would emerge a nucleus of graduates persuaded that there is more to Irish life than its divisions. And there are many other institutions that could be denationalized in this way. 